\title{
EFEKTIFITAS DEKOMPOSER DALAM PENANGANAN LEMAK INSTALASI PENGOLAHAN AIR LIMBAH PADA INSTALASI GIZI RUMAH SAKIT
}

\author{
Chrisal N. J. Rengkung ${ }^{1)}$, Agus Rokot ${ }^{2)}$ \\ ${ }^{1,)}$ RSJ Prof. dr. V. L. Ratumbuysang Manado \\ ${ }^{2)}$ Jurusan Kesehatan Lingkungan Poltekkes Kemenkes Manado \\ chrisalnovri21@gmail.com,agus_rokot@yahoo.com
}

\begin{abstract}
Fats are compounds that are not soluble in water, dissolve in organic solvents such as chloroform, ether or benzene, contain long chain hydrocarbon groups, and are in or originate from living organisms which when only allowed can have a negative impact on the environment and health. Decomposers as a means of decomposition processes in efficient fat handling, the hospital does not require large costs in handling fat. This type of research is an experiment, with the design of "Posttest Only Design", where the group is treated and then the results are observed. Data collection was obtained from measurements of decomposers I, II, and III decomposition processes using meter instruments. Data analysis using ANOVA test (F test)program software computer Statistical Product Service Solution (SPSS) with significance $\alpha=0.05$. The results showed the first decomposers with the addition of 1 liter / 2 days experienced decomposition on the 7th day following the second decomposers on the 9th day and the third decomposers on the 10th day. The Anova Test results ( $\mathrm{F}$ test) were $\mathrm{F}=8,953, \mathrm{p}=0.001(<0.05)$. These results indicate that decomposers are effective in handling fat wastewater treatment plants in hospital nutrition installations. It is recommended to the hospital to be able to condition this decomposer in terms of handling fat, because it makes it easy and does not require large costs and compensates for the volume of fat in the decomposer.
\end{abstract}

Keywords: Decomposer, Fat, Decomposition

\begin{abstract}
Abstrak. Lemak adalah senyawa-senyawa yang tidak larut dalam air, larut dalam pelarut-pelarut organik sperti kloroform, eter atau benzena, mengandung gugus-gugus hidrokarbon rantai panjang, dan berada dalam atau berasal dari organisme hidup yang bilamana hanya dibiarkan dapat memberikan dampak negatif bagi lingkungan dan kesehatan. Dekomposer sebagai sarana proses dekomposisi dalam penanganan lemak yang efisien maka rumah sakit tidak memerlukan biaya besar dalam penanganan lemak. Jenis penelitian ini adalah eksperimen, dengan rancangan "Postest Only Design", dimana kelompok diberi perlakuan dan selanjutnya diobservasi hasilnya. Pengumpulan data diperoleh dari pengukuran proses dekomposisi dekomposer I, II, dan III memakai instrumen meter. Analisis data menggunakan uji anova (uji F) program software komputer Statistical Produc Service Solution (SPSS) dengan kemaknaan $\alpha=0,05$. Hasil penelitian menunjukan dekomposer pertama dengan penambahan 1 liter/2 hari mengalami dekomposisi pada hari ke-7 menyusul dekomposer kedua pada hari ke-9 dan dekomposer ketiga pada hari ke-10. Hasil Uji Anova (uji F) adalah F = 8,953, p = $0.001(<0,05)$. Hasil ini menunjukkan dekomposer efektif dalam penanganan lemak instalasi pengolahan air limbah pada instalasi gizi rumah sakit. Disarankan kepada rumah sakit agar dapat mengkondisikan dekomposer ini dalam hal penanganan lemak, oleh karena memudahkan dan tidak memerlukan biaya yang besar serta mengimbangi volume lemak dalam dekomposer.
\end{abstract}

Kata kunci : Dekomposer, Lemak, Dekomposisi

Berdasarkan undang-undang No. 44 Tahun 2009 tentang rumah sakit, yang dimaksudkan dengan rumah sakit adalah institusi pelayanan kesehatan yang menyelenggarakan pelayanan kesehatan perorangan secara paripurna yang menyediakan pelayanan rawat inap, rawat jalan, dan gawat darurat.

Rumah sakit mempunyai misi memberikan pelayanan kesehatan yang bermutu dan terjangkau oleh masyarakat dalam rangka meningkatkan derajat kesehatan masyarakat. Tugas rumah sakit umum adalah melaksanakan upaya pelayanan kesehatan secara berdaya guna dan berhasil guna dengan mengutamakan penyembuhan dan pemulihan yang dilaksanakan secara serasi dan terpadu dengan peningkatan dan pencegahan serta pelaksanaan upaya rujukan (Soma, 2009

Untuk menyelenggarakan fungsinya, maka rumah sakit menyelenggarakan kegiatan (Febriansyah, 2011) :

1. Pelayanan medis.

2. Pelayanan dan asuhan keperawatan.

3. Pelayanan penunjang medis dan nonmedis.

4. Pelayanan kesehatan kemasyarakatan dan rujukan.

5. Pendidikan, penelitian dan pengembangan.

6. Administrasi umum dan keuangan.

Menurut undang-undang No. 44 tahun 2009

tentang rumah sakit, fungsi rumah sakit adalah: 
1. Penyelenggaraan pelayanan pengobatan dan pemulihan kesehatan sesuai dengan standar pelayanan rumah sakit.

2. Pemeliharaan dan peningkatan kesehatan perorangan melalui pelayanan kesehatan yang paripurna tingkat kedua dan ketiga sesuai kebutuhan medis.

3. Penyelenggaaan pendidikan dan pelatihan sumber daya manusia dalam rangka peningkatan kemampuan dalam pemberian pelayanan kesehatan.

4. Penyelenggaraan penelitian dan pengembangan serta pengaplikasian teknologi dalam bidang kesehatan dalam rangka peningkatan pelayanan kesehatan dengan memperhatikan etika ilmu pengetahuan bidang kesehatan.

Dalam penyelenggaraan fungsi rumah sakit sering terdapat berbagai permasalahan yang muncul oleh adanya kegiatan pelayanan kesehatan di rumah sakit. Masalah yang muncul oleh adanya aktivitas di dalam rumah sakit ialah limbah medis dan non medis berupa air limbah yang seringkali belum mendapat penanganan dengan baik.

Air limbah dari dapur banyak mengandung lemak. Lapisan lemak ini dapat mengganggu proses transfer oksigen dari udara ke dalam limbah, sehingga dapat mengganggu proses aerasi limbah. Untuk mengatasi hal ini maka lemak yang terdapat pada limbah dapur harus dipisahkan terlebih dahulu diawal proses pengolahan, sehingga air limbah sudah bebas dari lemak (Krisnawati dan Hardini, 2014)

Lemak merupakan salah satu sumber pencemar dalam limbah cair rumah sakit yang belum tertangani dengan baik. Limbah cair biasanya langsung dibuang ke badan air sehingga akan menyebabkan pencemaran. Lemak adalah salah satu kelompok golongan lipid, yaitu senyawa organik yang terdapat di alam serta tidak larut dalam air. Lemak adalah senyawa organik yang terdapat di alam serta tidak larut dalam air, tetapi larut dalam pelarut organik non-polar, misalnya dietil eter $\left(\mathrm{C}_{2} \mathrm{H}_{5} \mathrm{OC}_{2} \mathrm{H}_{5}\right)$, Kloroform $\left(\mathrm{CHCl}_{3}\right)$, benzena dan hidrokarbon lainnya. Lemak dapat larut pada bahan di atas kerena lemak mempunyai polaritas yang sama dengan pelarut tersebut. Lemak merupakan salah satu dari naggota lipid, yaitu merupakan lipit netral. Lipid itu sendiri dapat diklasifikasikan menjadi 4 kelas, yaitu : lipid netral, fosfatida, spingolipid, glikolipid (Rohman, 2016).

Penelitian sebelumnya yang dilakukan oleh Molle. R (2017) tentang uji coba dekomposer dalam penanganan sisa-sisa makanan pada rumah makan menunjukan bahwa dekomposer efektif dalam penanganan sisa-sisa makanan. Sampel yang ada dikelompokkan menjadi dua bagian dimana sampel pertama diuji pada daerah tepi pandai dengan hasil dekomposisi terjadi pada hari ke-4, sedangkan sampel yang kedua dilakukan pada dataran tinggi dan mengalami proses dekomposisi pada hari ke-11.

Sesuai dengan survei awal yang dilakukan pada rumah sakit yang ada bahwa lemak tangkapan grease trap instalasi pengolahan air limbah dari hasil aktivitas instalasi gizi hanya dibiarkan begitu saja pada bak tangkapan grease trap dengan tidak ada tindakan penanganan selanjutnya sehingga berdampak buruk pada estetika yang ada pada rumah sakit serta gangguan pada pengolahan air limbah rumah sakit oleh adanya penyumbatan padatan lemak pada instalasi pengolahan air limbah dan tentunya menghambat proses oksidasi oleh karena padatan lemak menutupi permukaan air limbah. Berdasarkan masalah yang ada, sehingga peneliti berminat untuk melakukan penelitian tentang efektifitas dekomposer dalam penanganan lemak instalasi pengolahan air limbah pada instalasi gizi rumah sakit (Alistigna, 2015)

\section{Metode}

Jenis penelitian ini adalah eksperimen, dengan rancangan "Postest Only Design", dimana kelompok diberi perlakuan dan selanjutnya diobservasi hasilnya (Sugiyono, 2008).

Eksperimen Postest
$\mathrm{X}$
02

\section{Hasil}

Dekomposer merupakan bioaktivator perombak bahan organik biologis yang diracik khusus untuk meningkatkan efisiensi dekomposisi sisa-sisa tanaman, mengurangi penyebab penyakit, masalah lingkungan pada penumpukan sampah (Palupi N.P, 2015).

Wadah dekomposer yang digunakan dibuat dengan alat dan bahan-bahan yang sederhana dengan waktu pembuatan yang tidak terlalu lama. Lemak yang digunakan dalam pengujian 
dekomposer adalah lemak yang dikumpulkan dari aktivitas Instalasi Gizi di Rumah Sakit dan berada pada bak penampung/penyaring lemak (Grease Trap) Instalasi Pengolahan Air Limbah (IPAL) Rumah Sakit. Perlakuan dilakukan dengan mengambil lemak dan memasukkan lemak pada wadah dekomposer yang berjumlah tiga buah dengan perbandingan $1: 3: 5$ (liter), yaitu dekomposer pertama penambahan 1 liter/2 hari, dekomposer kedua penambahan 3 liter/2 hari, dekomposer ketiga penambahan 5 liter/2 hari. Prosesnya berlangsung selama 14 hari.

1. Hasil Uji Penurunan Lemak Dari Proses Dekomposisi Dekomposer I, II, Dan III.

Pengamatan penurunan lemak dilakukan dari hari pertama hingga hari ke empat belas. Hasil pengamatan menunjukkan bahwa dekomposer berperan penting dalam proses dekomposisi lemak hingga hari ke-14. Proses dekomposisi lemak oleh dekomposer teruji dari hasil penurunan lemak, adanya perubahan warna lemak, dan timbulnya spora dalam lemak yang mengindikasikan adanya mikroorganisme dekomposer dalam lemak.

Penurunan lemak terjadi pada semua dekomposer yang berjumlah tiga buah, dengan kondisi penurunan berbeda-beda tiap dekomposer. Masing-masing penambahan lemak pada dekomposer berbeda-beda yaitu 1 liter, 3 liter, dan 5 liter.

Hasil penurunan lemak pada wadah dekomposer ini terlihat bahwa dekomposer berfungsi dalam dekomposisi lemak baik dekomposer I, II, dan III, dengan demikian dekomposer efektif dalam penurunan lemak.

\section{Lama Waktu Dekomposisi Lemak}

Lama waktu dekomposisi lemak diukur saat hari pertama lemak diletakkan dalam dekomposer sampai terjadi dekomposisi. Waktu yang dibutuhkan hingga terjadinya proses dekomposisi bervariasi antara dekomposer pertama, kedua dan ketiga. Waktu optimal dekomposisi lemak pada dekomposer pertama terjadi pada hari ketujuh dengan adanya penurunan volume lemak sebesar 0.8 liter. Dekomposer kedua memerlukan waktu optimal selama sembilan hari hingga mengalami proses dekomposisi dengan penurunan lemak pertama sebesar 0.8 liter, dan dekomposer ketiga mengalami dekomposisi pada hari kesepuluh dengan penurunan pertama sebesar 0.7 liter.

\section{Kualitas Fisik Lemak Hasil Dekomposisi}

Hasil pengamatan yang dilakukan terhadap kualitas fisik lemak oleh karena adanya proses dekomposisi menunjukan bahwa lemak mengalami perubahan fisik baik warna, bentuk, dan bau oleh karena adanya peran mikroorganisme sebagai dekomposer dalam lemak. Seperti yang telah dijelaskan pada uraian sebelumnya bahwa lemak mengalami penurunan volume pada hari ketujuh, kesembilan, dan kesepuluh oleh karena adanya peran dan fungsi dekomposer, maka pada hasil kualitas fisik inipun mengalami hal yang sama yaitu menunjukkan perubahan fisik pada hari ketujuh, kesembilan dan kesepuluh.

Untuk lebih jelasnya ditunjukkan pada tabel berikutini:

Tabel 1. Kualitas Fisik Lemak Pada Dekomposer I, II, III

\begin{tabular}{|c|c|c|c|}
\hline \multirow{2}{*}{$\begin{array}{c}\text { Wadah } \\
\text { Dekomposer }\end{array}$} & \multicolumn{3}{|c|}{ Kualitas Fisik Lemak } \\
\hline & Bau & Warna & Bentuk \\
\hline $\begin{array}{l}\text { Dekomposer } \\
\text { I }\end{array}$ & $\begin{array}{l}\text { Bau sama seperti } \\
\text { penambahan hari ke-1 } \\
\text { hingga hari ke-14 }\end{array}$ & $\begin{array}{l}\text { Mengalami perubahan warna dari abu-abu } \\
\text { kekuningan menjadi kecoklatan pada hari } \\
\text { ke- } 7 \text {, hari ke- } 8 \text { muncul bercak-bercak putih }\end{array}$ & $\begin{array}{l}\text { Halus, berspora, } \\
\text { sedikit berlendir }\end{array}$ \\
\hline $\begin{array}{c}\text { Dekomposer } \\
\text { II }\end{array}$ & $\begin{array}{l}\text { Bau sama seperti } \\
\text { penambahan hari ke-1 } \\
\text { hingga hari ke-14 }\end{array}$ & $\begin{array}{l}\text { Mengalami perubahan warna dari abu-abu } \\
\text { kekuningan menjadi kecoklatan pada hari } \\
\text { ke- } 9 \text {, hari ke- } 11 \text { muncul bercak putih }\end{array}$ & $\begin{array}{l}\text { Halus, berspora, } \\
\text { sedikit berlendir }\end{array}$ \\
\hline $\begin{array}{c}\text { Dekomposer } \\
\text { III }\end{array}$ & $\begin{array}{l}\text { Bau sama seperti } \\
\text { penambahan hari ke-1 } \\
\text { hingga hari ke-14 }\end{array}$ & $\begin{array}{l}\text { Mengalami perubahan warna dari abu-abu } \\
\text { kekuningan menjadi kecoklatan pada hari } \\
\text { ke-10., hari ke- } 12 \text { muncul bercak putih }\end{array}$ & $\begin{array}{l}\text { Halus, berspora, } \\
\text { sedikit berlendir }\end{array}$ \\
\hline
\end{tabular}




\section{Suhu Dalam Proses Dekomposisi}

Panas dihasilkan dari aktivitas mikroorganisme dalam lemak. Ada hubungan langsung antara peningkatan suhu dengan konsumsi oksigen yang terjadi pada proses dekomposisi lemak. Hasil pengukuran suhu antara dekomposer pertama, kedua dan ketiga bervariasi satu sama lainnya. Suhu terendah hasil pengukuran adalah $29{ }^{\circ} \mathrm{C}$ dan tertinggi adalah $32,5^{\circ} \mathrm{C}$.

\section{Kelembaban Dalam Proses Dekomposisi.}

Kelembaban diukur selama penelitian dari hari ke-1 hingga hari ke-14. Hasil kelembapan yang diukur bervariasi antara dekomposer I, II, dan III oleh karena pengaruh iklim dan cuaca yang cenderung berubah-ubah. Kelembaban terendah adalah $63 \%$ dan kelembaban tertinggi adalah $69 \%$.

\section{Derajat Keasaman (pH) Dalam Proses Dekomposisi}

Pengukuran derajat keasaman $(\mathrm{pH})$ dilakukan sama seperti pengukuran suhu dan kelembapan, yaitu terhitung dari hari ke-1 perlakuan hingga hari ke-14. Derajat keasaman terendah adalah 5,2 dan tertinggi adalah 7 .

\section{Pembahasan}

\section{Penurunan Lemak Dari Proses}

\section{Dekomposisi Dekomposer I, II, Dan III.}

Berdasarkan hasil penelitian yang dilakukan terhadap dekomposer pertama, kedua, dan ketiga terjadi perbedaan penurunan volume lemak yang signifikan. Dekomposer pertama dengan penambahan 1 liter/2 hari mengalami penurunan mulai pada hari ke-7 hingga hari ke-14 selama 8 hari berturut-turut dengan total penurunannya sebesar 5,7 liter atau 81,4\% dari akumulasi penambahan lemak per dua hari. Dekomposer kedua untuk penambahan lemak 3 liter/2 hari mengalami penurunan lemak mulai pada hari ke-9 hingga hari ke-14 selama 6 hari berturutturut dengan total penurunan lemak sebesar 4,8 liter atau $22,8 \%$. Sedangkan dekomposer ketiga dengan penambahan lemak 5 liter/2 hari mengalami penurunan lemak pada hari ke-10 hingga hari ke-14 selama 5 hari berturut-turut dengan total penurunan sebesar 4 liter atau $11,4 \%$. Terlihat bahwa dekomposer pertama lebih dahulu mengalami proses dekomposisi dibandingkan dengan dekomposer II dan III yang mana proses dekomposisi sudah terjadi pada hari ke-7 dengan persentasi penurunan mencapai $81,4 \%$ lebih besar dibandingkan dekomposer II dan III.

Proses dekomposisi yang terjadi antara dekomposer pertama, kedua dan ketiga menunjukkan efektifnya dekomposer terhadap penanganan lemak rumah sakit. Sekalipun dekomposer kedua dan ketiga mengalami keterlambatan proses dekomposisi dan besaran penurunan disebabkan dekomposer kedua mengalami dekomposisi pada hari ke-9 dan dekomposer ketiga mengalami dekomposisi pada hari ke-10 tetapi kedua dekomposer tetap menunjukan perbedaan volume lemak dari akumulasi lemak mulai dari hari pertama penambahan lemak hingga hari keempat belas, sehingga dekomposer II dan III tetap dikatakan efektif.

Hasil uji Anova yang dilakukan terhadap efektifitas dekomposer I, II, dan III menunjukan nilai $\mathrm{F}=8,953$ dan $\mathrm{p}=0,001$ menunjukan terdapat perbedaan yang signifikan antara dekomposer I, II, dan III terhadap proses dekomposisi lemak. Perbedaan ini terlihat dari nilai $\mathrm{p}<\alpha=0,05$. Perbedaan antara dekomposer juga terlihat jelas dari Uji Post Hoc yang dilanjutkan dari Uji Anova. Uji Post Hoc antara dekomposer I dengan dekomposer II menunjukkan nilai $\mathrm{p}=$ 0,002 dan dekomposer I dengan dekomposer III $\mathrm{p}=0,000$ di mana nilai $\mathrm{p}$ keduanya kurang dari $\alpha=0,05$ yang membuktikan bahwa terdapat perbedaan yang signifikan antara dekomposer I, II, dan III.

\section{Lama Waktu}

Perbedaan waktu penurunan dan volume penurunan lemak pada ketiga dekomposer disebabkan oleh kemampuan dekomposer dalam memperoleh kecukupan oksigen pada proses dekomposisi. Ruang udara yang ada pada dekomposer kedua dan ketiga sangat kecil oleh karena padatnya volume lemak dalam wadah dibandingkan dengan wadah dekomposer pertama yang memiliki ruang udara yang besar sehingga memungkinkan dekomposer memperoleh oksigen yang besar. Padatan lemak dalam suatu wadah dekomposer sangat 
memengaruhi aktivitas mikrooganisme untuk mencari makan pada dekomposisi aerob, oksigen harus cukup tersedia di dalam tumpukan. Apabila kekurangan oksigen, proses dekomposisi tidak dapat berjalan. Agar tidak kekurangan oksigen, tumpukan kompos harus dibalik minimal seminggu sekali. Selain itu, dapat juga dilakukan dengan cara force aeration, yaitu menghembuskan udara memakai kompresor. Bisa juga dengan efek cerobong, yaitu memasukkan udara melalui cerobong. Namun, pemberian aerasi yang terbaik adalah dengan pembalikan bahan (Patanga A dan Yuliarti N, 2016).

Proses dekomposisi lemak pada dekomposer pertama, kedua, dan ketiga terjadi seiring dengan adanya aktivitas mikroorganisme yang ada, begitu juga dengan keseimbangan suhu, kelembapan, dan derajat keasaman pada wadah dekomposer. Waktu optimal yang diperlukan hingga terjadinya proses dekomposisi adalah tujuh hari diukur dari hari pertama penambahan lemak dalam wadah dekomposer. Adalah dekomposer pertama yang mengalami proses dekomposisi terlebih dahulu yaitu pada hari ketujuh diikuti oleh dekomposer kedua pada hari kesembilan dan dekomposer ketiga pada hari kesepuluh. Dari hasil pengamatan terhadap lama waktu dekomposisi pada tiap dekomposer diukur dengan adanya tanda perubahan fisika, kimia, biologi dan bahkan penurunan lemak selama jangka waktu penelitian yaitu 14 hari.

Berdasarkan lama waktu yang ditetapkan diawal penelitian yaitu selama 14 hari, maka pengujian dekomposer dalam proses dekomposisi lemak dikatakan efektif karena telah terjadi proses dekomposisi. Meskipun ada perbedaan lama waktu dekomposisi antara dekomposer pertama, kedua, dan ketiga tetapi dari ketiga dekomposer ini telah terjadi proses dekomposisi lemak.

\section{Kualitas fisik lemak hasil dekomposisi}

Proses dekomposisi suatu bahan organik tentu sejalan dengan adanya perubahan kualitas fisik bahan organik yang terjadi oleh karena reaksi kimia yang ada dalam suatu bahan organik. Proses ini menimbulkan perubahan pada kondisi akhir bahan organik setelah adanya peran mikroorganisme yang berfungsi sebagai dekomposer dalam proses penguraian.

Kondisi inilah yang terjadi pada lemak instalasi pengolahan air limbah pada instalasi gizi rumah sakit. Proses dekomposisi berjalan baik oleh karena berfungsinya dekomposer dalam lemak, yang mengakibatkan perubahan kualitas fisik lemak. Sesuai dengan hasil pengamatan yang dilakukan terhadap dekomposer I, II dan III menunjukkan adanya perubahan fisik yang mengarah pada perubahan warna, bentuk, dan bau pada lemak, di mana warna lemak pada awal pengambilan sampel berwarna abu-abu kekuning-kuningan berubah menjadi kecoklatan bahkan muncul bercak-bercak putih pada saat berjalannya penelitian hingga akhir penelitian. Bau yang ada dalam dekomposer mengindikasikan aktivitas mikroorganisme dekomposer yang melepaskan asam saat terjadinya proses dekomposisi bahan organik.

\section{Suhu}

Suhu pengomposan yang ideal adalah $30-50{ }^{\circ} \mathrm{C}$. Suhu yang terlalu rendah akan menyebabkan mikroorganisme tidur (dorman), jika terlalu panas ia akan mati (Patanga A, Yuliarti N, 2016). Sedangkan Nisa K, dkk (2016) menjelaskan bahwa temperatur yang berkisar antara 30-60 ${ }^{\circ} \mathrm{C}$ menunjukkan aktivitas pengomposan yang cepat. Suhu yang lebih tinggi dari $60{ }^{\circ} \mathrm{C}$ akan membunuh sebagian mikroba dan hanya mikroba thermofilik saja yang akan tetap bertahan hidup.

Dari hasil pengukuran yang dilakukan terhadap ketiga dekomposer menunjukan bahwa suhu rata-rata dari ketiga dekomposer ini adalah ; dekomposer pertama $31,1{ }^{\circ} \mathrm{C}$, dekomposer kedua $31,6{ }^{\circ} \mathrm{C}$, dekomposer ketiga $31,8{ }^{\circ} \mathrm{C}$. Suhu rata-rata yang ada pada ketiga dekomposer berada pada kisaran suhu optimal bagi mikroorganisme melakukan proses dekomposisi.

\section{Kelembaban}

Kelembaban yang didapat dari pengukuran pada dekomposer mengalami fluktuasi dan tidak stabil sama seperti saat pengukuran suhu. Kejadian ini dipengaruhi 
oleh cuaca yang ada yang sering berubahubah setiap saat yang terkadang hujan dan terkadang panas. Dari hasil pengukuran kelembaban pada ketiga dekomposer didapat bahwa kelembaban minimun pada dekomposer pertama adalah $63 \%$ sedangkan kelembaban maksimum adalah 68\%. Pada dekomposer kedua kelembaban minimun adalah $64 \%$ sedangkan kelembaban maksimum 69\%. Pada dekomposer ketiga hasil kelembaban minimun adalah $64 \%$ dan kelembaban maksimum $69 \%$.

Kelembaban memegang peranan yang sangat penting dalam proses metabolisme mikroba dan secara tidak langsung berpengaruh pada suplai oksigen. Mikroorganisme dapat memanfaatkan bahan organik tersebut larut dalam air. Kelembaban 40-60\% adalah kisaran optimal untuk metabolisme mikroba. Apabila kelembaban di bawah $40 \%$ aktivitas mikroba akan mengalami penurunan dan akan lebih rendah lagi pada kelembaban $15 \%$ (Nisa K,dkk. 2016).

\section{Derajat keasaman (pH)}

Nisa K, dkk (2016) menyebutkan bahwa proses pengomposan dapat terjadi pada kisaran $\mathrm{pH}$ yang lebar. $\mathrm{pH}$ yang optimal untuk proses pengomposan berkisar antara 6,5 sampai 7,5. Proses pengomposan sendiri akan menyebabkan perubahan pada bahan organik dan $\mathrm{pH}$ bahan itu sendiri. Sebagai contoh proses pelepasan asam, secara temporer atau lokal akan menyebabkan penurunan $\mathrm{pH}$ (keasaman), sedangkan produksi amonia dari senyawa-senyawa yang mengandung nitrogen akan meningkatkan $\mathrm{pH}$ pada fase-fase awal pengomposan, $\mathrm{pH}$ kompos yang sudah matang biasanya mendekati netral.

Derajat keasaman $(\mathrm{pH})$ yang didapat dari hasil pengukuran pada dekomposer pertama, kedua dan ketiga awalnya sangat rendah yaitu berkisar diantara 5,0 sampai 5,5. Kondisi ini terjadi oleh karena aktivitas mikroorganisme yang ada dalam lemak yang melepaskan asam seiring dengan proses dekomposisi yang terjadi.

\section{Kesimpulan}

1. Dekomposer efektif dalam penanganan lemak instalasi pengolahan air limbah pada instalasi gizi rumah sakit, di mana dari ketiga dekomposer yang ada menunjukan terjadinya proses dekomposisi.

2. Proses dekomposisi dengan adanya penurunan lemak berbeda-beda pada ketiga dekomposer, di mana dekomposer pertama mengalami proses dekomposisi dengan volume pernurunan lemak pertama sebesar 0.8 liter. Dekomposer kedua mengalami penurunan volume lemak pertama sebesar 0.8 liter. Dekomposer ketiga mengalami penurunan lemak pertama sebesar 0.7 liter

3. Lemak mengalami perubahan kualitas dari segi fisik, di mana terjadi perubahan warna mulai dari abu-abu kekuningan hingga kecoklatan, bau, dan bentuk sesuai dengan proses dekomposisi yang ada pada ketiga dekomposer.

4. Suhu pada ketiga dekomposer berbeda-beda, oleh karena volume lemak yang ada yang mempengaruhi proses dekomposisi yang berkaitan dengan aerasi dalam lemak. Suhu rata-rata pada ketiga dekomposer adalah : dekomposer pertama $31,1{ }^{\circ} \mathrm{C}$, dekomposer kedua $31,6{ }^{\circ} \mathrm{C}$, dekomposer ketiga $31,8{ }^{\circ} \mathrm{C}$.

5. Kelembaban pada ketiga dekomposer memiliki nilai kelembaban antara 60-70\%. Hal ini dikarenakan cuaca yang ada dilokasi penelitian yang sering berubah-ubah.

6. Derajat keasaman pada ketiga dekomposer mimiliki $\mathrm{pH}$ yang rendah pada awal pengukuran dimana berada pada kisaran 5,25,3 dan bertambah seiring dengan berjalannya waktu hingga mencapai ketingkat yang optimum yaitu pada kisaran 6,5-7.

\section{Saran}

1. Mengkondisikan dekomposer ini dalam hal penanganan lemak, oleh karena memudahkan dan tidak memerlukan biaya yang besar serta mengimbangi volume lemak dalam dekomposer.

2. Perlu melakukan penelitian lebih lanjut menyangkut laju aerasi, porositas, kadar air, rasio $\mathrm{C} / \mathrm{N}$ yang dapat mempengaruhi tingkat dekomposisi suatu bahan organik. 


\section{Daftar Pustaka}

Alistigna. 2015. Pengertian Dekomposer dan Contohnya. http://budisma.net. diakses tanggal 21 Oktober 2017.

Depkes RI. 2009. Undang-undang RI No.44 Tentang Rumah Sakit, Jakarta.

Febriansyah R.A. 2011. Pengujian Inokulan Konsorsium Dekomposer Beragen Hayati Dalam Laju Dekomposisi Jerami Selama Masa Inkubasi Yang Dilakukan Di Rumah Kaca. Etheses.uinmalang.ac.id/922/6/06520001\%20Bab\% 202. Diakses tanggal 21 Oktober 2017.

Krismawati A, Hardini D. 2014. Kajian Beberapa Dekomposer Terhadap Kecepatan Dekomposisi Sampah Rumah Tangga. Jurnal Buana Sains Vol. 14 No. 2: 79-89.

Molle R. 2017. Uji Coba Dekomposer Dalam Proses Dekomposisi Sampah Organik (Sisa Makanan) Di Tepi Pantai Dan Pegunungan, Skripsi, Politeknik Kesehatan Kemenkes Manado, Manado.

Nisa K, dkk. 2016. Memproduksi Kompos Dan Mikro Organisme Lokal (MOL). Bibit Publisher, Jakarta

Patanga N, Yuliarti N. 2016. Pembuatan Aplikasi Dan Bisnis Pupuk Organik Dari Limbah Pertanian Peternakan Dan rumah Tangga, Gramedia, Jakarta.
Palupi N. P. 2015. Karakter Kimia Kompos Dengan Dekomposer Mikroorganisme Lokal Asal Limbah Sayuran (The Chemist Character Of Compost With Decomposer Of Local Microorganism from Vegetables Waste). Jurnal Fakultas Pertanian Universitas Mulawarman Samarinda Kampus Gunung Kelua Samarinda email : nurulpuspita2908@gmail.com Volume 40 Nomor 1, Pebruari 2015 Halaman 5460. Diakses tanggal 21 oktober 2017.

Rohman A. 2016. Lipid : Sifat-Sifat Fisika Kimia Dan Analisisnya, Pustaka Pelajar, Yogjakarta.

Soma S. 2009. Dekomposisi Sampah Bahan Organik Rumah Tangga Menggunakan Cacing Tanah Eisenia Fetida dan Lumbricius Rubellus. Jurnal Purifikasi. (20:129-134).

Siswanto H. 2003. Kamus Populer Kesehatan Lingkungan, EGC, Jakarta.

Sugiyono. 2008. Metode Penelitian Kuantitatif Kualitatif dan $R \& D$, Alfabeta, Bandung. Undang-Undang Republik Indonesia No. 44 Tahun 2009 Tentang Rumah Sakit. 